Interfaces

\title{
The mathematician, the Surrealist, and the poet are of imagination all compact: Man Ray's Shakespearean Equations
}

\section{Anne-Kathrin Marquardt}

\section{OpenEdition}

Journals

Electronic version

URL: http://journals.openedition.org/interfaces/659

DOI: 10.4000/interfaces.659

ISSN: 2647-6754

Publisher:

Université de Bourgogne, Université de Paris, College of the Holy Cross

\section{Printed version}

Date of publication: 12 December 2019

Number of pages: $99-128$

ISSN: 1164-6225

\section{Electronic reference}

Anne-Kathrin Marquardt, "The mathematician, the Surrealist, and the poet are of imagination all compact: Man Ray's Shakespearean Equations", Interfaces [Online], 42 | 2019, Online since 12 December 2019, connection on 04 January 2021. URL: http://journals.openedition.org/interfaces/659 ; DOI: https://doi.org/10.4000/interfaces.659

\section{(c) (†)}

Les contenus de la revue Interfaces sont mis à disposition selon les termes de la Licence Creative Commons Attribution 4.0 International. 


\title{
THE MATHEMATICIAN, THE SURREALIST, AND THE POET ARE OF IMAGINATION ALL COMPACT: MAN RAY'S SHAKESPEAREAN EQUATIONS
}

\author{
Anne-Kathrin Marquardt \\ Lycée Jeanson de Sailly
}

\begin{abstract}
Man Ray's series of paintings entitled Shakespearean Equations remains largely unknown even today, despite the artist's fame. Perhaps that is partly because, like many Surrealist works, it so stubbornly resists interpretation; it is difficult to even grasp what one is looking at. The paintings depict mathematical models and their only Shakespearean characteristics are their titles, taken directly from Shakespeare's canon. Nevertheless, I argue that a fruitful analysis is possible by understanding the pictures in relation to Shakespeare's texts, the reception of Shakespeare in the twentieth century, and the reception of non-Euclidean geometry in artistic circles at the time. My study thus hinges on an assessment of the context in which Man Ray produced these works. But it also takes a closer look at two paintings in the series, uncovering the textual and pictorial sources they reference, parsing the layers of meaning which are thus built up. This paper does not set itself the impossible task of producing a definitive interpretation, which would, among other things, be contrary to the Surrealist spirit. I rather hope to explore what this particular act of appropriation uncovers about the reception of Shakespeare and mathematics.
\end{abstract}

\section{Résumé}

La série de peintures intitulée Shakespearean Equations par Man Ray est encore peu connue, malgré la renommée de l'artiste. Peut-être est-ce parce que ces images, comme tant d'œuvres surréalistes, résistent au travail d'interprétation ; il est même difficile de saisir précisément ce qui est représenté. Ces tableaux montrent en réalité des modèles mathématiques ; seuls leurs titres, puisés directement dans le répertoire shakespearien, les lient au dramaturge. Néanmoins, cet article s'appuie 
sur l'hypothèse suivante : qu'une étude féconde est possible pour peu que l'on comprenne ces images par le prisme des pièces de Shakespeare, de la façon dont le vingtième siècle s'est approprié ces textes, et la réception de la géométrie non Euclidienne à la même époque. L'analyse proposée se fonde ainsi sur le contexte dans lequel Man Ray produisit ces œuvres. Elle élargit le propos en suggérant une interprétation de deux tableaux de la série; leurs sources textuelles et picturales sont examinées afin d'extraire les significations multiples portées par ces images. Cet article n'a évidemment pas pour ambition d'imposer une interprétation définitive, ce qui serait entre autres contraire à l'esprit surréaliste. Il se propose plutôt d'apporter un nouvel éclairage sur la question de l'appropriation de l'œuvre shakespearienne et des mathématiques.

\section{Introduction}

Must an adaptation necessarily be analysed as such, as a work that derives from another? This question - often raised in academic studies dealing with intertextuality, adaptation and appropriation - is perhaps particularly relevant to an analysis of Man Ray's Shakespearean Equations, a series of paintings which, prima facie, displays no Shakespearean characteristic whatsoever. The title of the series as a whole is an obvious reference to the Bard. In addition, each individual painting bears the title of a Shakespeare play. However, what they actually depict is a range of mathematical models with no obvious connection to Renaissance theatre. Is it therefore valid, or legitimate, to treat these paintings as adaptations of literary and / or mathematical references - even when the word "adaptation" is understood in its widest possible sense? Linda Hutcheon, in her seminal work $A$ Theory of Adaptation, defines adaptations as "deliberate, announced, and extended revisitations of prior works", as "both a product and a process of creation and reception" (Hutcheon 2006, xiv). Do these criteria apply? Man Ray announces his theatrical reference clearly and deliberately (this is less true of the mathematical reference, as we shall see). If the definition of "extended" is used flexibly enough to accommodate the change of medium from text to painting, then an entire series using Shakespearean and geometrical references fits the description. Moreover, the paintings are products of a process of creation which involved an examination of texts and mathematics on the artist's part. The only open question remains that of reception. Here we come full circle to the issue raised above. The problem is that, to some extent, adaptation lies in the eye of the beholder, who may not perceive the relationship between two works. Hutcheon, nevertheless, argues that any meaningful study of adaptation is not only legitimate in analysing two works as connected such an analysis is in fact a necessity: 
[...] seen from the perspective of its process of reception, adaptation is a form of intertextuality: we experience adaptations (as adaptations) as palimpsests through our memory of other works that resonate through repetition with variation. (Hutcheon 2006, 8, Hutcheon's emphasis)

But this approach to the reception of adaptations raises a new question. Indeed the underlying assumption is that the readers and spectators on the receiving end of an adaptation have sufficient "memory" of the first work to see the connection and let it "resonate." Adaptation can only function as adaptation if received by an "interpretive community" (Fish 1980) both willing and able to perceive it as such. It is in light of these issues that I wish to analyse Man Ray's Shakespearean Equations series, standing as it does at the crossroads among mathematics, literature and art. What do different interpretive communities make of a body of work that draws on areas of knowledge so widely apart? If one assumes - as I do in this paper - that understanding it as an adaptation is not only legitimate, but also necessary for a full understanding of the series, then what vision of Shakespeare and mathematics emerges in these paintings? I shall start by retracing the story behind Shakespearean Equations, before moving on to an analysis of the place of literature and mathematics in the paintings, based on a study of two pictures in the series.

\section{The story behind Shakespearean Equations}

Each painting may bear the title of a Shakespeare play, but what they actually depict is a series of mathematical models which Man Ray found in Paris. Kept at the Institut Henri Poincaré (IHP), the models were produced around 1900 to teach students about complex geometric shapes. ${ }^{50}$ They had fallen into disuse and were "covered with dust" in a "dim hall" (Man Ray 2016, 183) by the time Max Ernst took his friend Man Ray to see them at some point between 1934 and 1936.Man Ray may have been interested in the models due to his training in technical drawing (Man Ray 1988, 17-18). The Dadaist and Surrealist movements in general had found inspiration in the new kinds of geometry that

50 An interview with art historian Edouard Sebline at the IHP discussing Man Ray's work enables one to see a few of the objects in three dimensions: www.youtube.com/watch? $\mathrm{v}=$ TmYbyuivAfo. A selection of models (not necessarily the ones Man Ray painted) can be seen on the IHP's Pinterest page: www.pinterest.co.uk/bibliothequeihp/ mathematical-models/. An interview with the former IHP Director Cédric Villani features the objects: www. youtube.com/watch?v=HSadET0Gj5E (see also IHP 2017). The IHP also produced a documentary on the subject, directed by Quentin Lazzarotto and entitled Man Ray et les équations shakespeariennes (www.imdb.com/title/

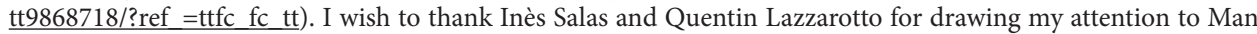
Ray's series; my thanks are also due to the wonderful librarians of the Institut National d'Histoire de l'Art, Paris. I would also like to acknowledge Marie-Odile Bernez and the anonymous reviewers who helped improve this paper before publication in Interfaces. 
had developed in the nineteenth century and were fascinated by objects. ${ }^{51}$ The mathematical models allowed Man Ray to pursue both interests. He then produced a series of photographs of the models. ${ }^{52}$ Capitalising on his experience as a fashion photographer, he staged the objects in a veritable miseen-scène. Using dramatic lighting, close cropping, high contrast, an indeterminate background and, sometimes, combinations of models, he took them out of their original context and turned them into what Surrealists termed "found objects." The photographs were displayed in Paris in 1936, as well as London and New York. ${ }^{53}$

Forced to leave France in a hurry after the outbreak of the Second World War, Man Ray would not see his pictures again for several years. Having relocated to Hollywood, he managed to retrieve many works in 1947. Between 1947 and 1954, he then produced a series of paintings based on the photographs. As Wendy Grossman points out, precision was highly important to him: "to paint faithful representations of each mathematical model, closely replicating the angles and perspective, Man Ray conceivably used copy negatives mounted into slide film holders to project images in reversed tones" (Grossman and Sebline 2015, 54). In the paintings, he does not only add colour to the pictures, he also combines the mathematical models in new ways, uses a variety of other motifs (a peach, butterflies, the leg of a table...), imagines a background. Often this enhances the anthropomorphic qualities of

51 Duchamp was renowned for his "readymades," the most famous of which is perhaps a urinal which he turned into his Fountain (1917, www.philamuseum.org/collections/permanent/92488.html). The Surrealists developed the concept of the "found object," an everyday object transformed by the artist into something incongruous and poetic. Man Ray himself produced a number of such works in his life, which he called "objects of my affection" (Man Ray 1983). Among them his Non-Euclidean Object (1932, www.centrepompidou.fr/id/coXMEr/rdq4LAb/ en) betrays an early interest in mathematics. Some of Man Ray's photographs of the IHP models appeared in a 1936 magazine alongside an article by André Breton entitled "Crise de l'objet" (Breton 1936), which is one of many Surrealist texts on this question.

52 Only two examples shall be given here. Not used in the later series of paintings is this photograph: www.mfah.org/ art/detail/16511. Part of the painting Antony and Cleopatra is this picture: www.centrepompidou.fr/id/cgrMnn/ rgzKdRK/en.

53 Some of Man Ray's photographs of the mathematical models were shown at the Exposition surréaliste d'objets (Surrealist Exhibition of Objects), along with some of the models themselves, at the art gallery Charles Ratton in Paris from 22 May to 29 May 1936. This exhibition included a variety of "found objects" such as glasses distorted by a volcanic eruption, stones with astonishing shapes or tribal artefacts. A special issue of Cahiers d'art was published for the occasion and featured essays by Christian Zervos and André Breton, illustrated with Man Ray's photographs. They were subsequently presented at the International Surrealist Exhibition at London's New Burlington Galleries from 11 June to 4 July 1936, and they were part of Fantastic Art, Dada, Surrealism which ran at New York's MoMA from 7 December 1936 to 17 January 1937. 
the models, which had already been visible in some of the photographs, even further. The series was first shown at the Copley Galleries in Beverly Hills in late $1948 .{ }^{54}$ The only other major exhibition to display the series would be held 67 years later, in a show that toured the world in 2015-2016 under the title Man Ray, Human Equations, A Journey from Mathematics to Shakespeare. ${ }^{55}$

\section{Why Shakespeare?}

Given that the paintings do not depict anything that looks remotely like a scene from a Shakespeare play, the choice of title may seem surprising and it remains unclear when and why the decision was made. When the photographs were first taken in the 1930s, Breton had endowed them with French titles which, in true Surrealist fashion, he claimed were perfectly random (Breton 1936, 26). But when it came to the paintings, Man Ray evidently rejected these in favour of his own. For the 1948 exhibition, the title of the series became Equations for Shakespeare, later changed to Shakespearean Equations (Baldwin 1989, 263); each individual painting was given the title of a Shakespeare play. This idea may have appeared only quite late into the process. In a postcard to Man Ray's niece Naomi Siegler (later Savage) dated 28 April 1948, his wife Juliet writes "Man Ray is painting wonderful human equations, that's what he calls the new series of paintings" (Grossman and Sebline 2015, 16). In his autobiography, the artist states that he gave the series its definitive title after he had completed about fifteen pictures (Man Ray 1988, 291).

54 The show at the Copley Galleries in Beverly Hills ran from 14 December 1948 to 9 January 1949. The Shakespearean Equations series was later displayed at the Furstenberg Gallery in Paris from 1 June to 15 June 1954. Only three of the paintings were produced after the Copley show (Much Ado About Nothing and Hamlet in 1949, Romeo and Juliet in 1954), taking the total number of paintings to twenty-three. For As You Like It, The Merchant of Venice and Hamlet there are two versions each, although the location of the earlier Hamlet, dating to 1948, is now unknown (Grossman and Sebline 2015, 225), which takes the number of extant pictures down to twenty-two. A few paintings appear not to be based on the mathematical models. An odd one out is also Equation (1947), which does not bear a Shakespearean title despite being part of the series. The complete list of Shakespeare plays painted by Man Ray is as follows: All's Well That Ends Well, Antony and Cleopatra, As You Like It, The Comedy of Errors, Hamlet, Julius Caesar, King Lear, Love's Labour's Lost, Macbeth, Measure for Measure, The Merchant of Venice, The Merry Wives of Windsor, A Midsummer Night's Dream, Much Ado About Nothing, Othello, Romeo and Juliet, The Taming of the Shrew, The Tempest, Twelfth Night.

55 Man Ray, Human Equations, A Journey from Mathematics to Shakespeare could be seen from 7 February to 10 May 2015 at the Phillips Collection in Washington, D.C., from 11 June to 20 September 2015 at the NY Carlsberg Glyptotek in Copenhagen, and from 20 October 2015 to 23 January 2016 at the Israel Museum in Jerusalem. The Phillips's Pinterest page has numerous examples of the works displayed: www.pinterest.com/phillipsdc/man-rayhuman-equations-a-journey-from-mathematics/. The accompanying catalogue remains an invaluable source for research on the series. 
On the other hand, it may well be that Man Ray had conceived of the Shakespeare project much earlier, when he was taking the photographs in the 1930s. ${ }^{56}$ On the stretcher of his 1954 painting Romeo and Juliet (which is part of the series), he inscribed "projet de 1936" ("project of 1936," Grossman and Sebline 2015, 46). Moreover, a small album of photographs survives entitled Contacts for Shakespearean Equations, dated 1935-1948, but its mysterious annotations unfortunately offer no definitive clue as to Man Ray's intentions. ${ }^{57}$ In an open letter to Breton, Man Ray explains his choice of Shakespearean titles for the paintings. Although he rejects his friend's earlier ideas for the photographs, Man Ray adds that he hopes his are as arbitrary as Breton's.

In returning to the mathematical objects as a source of material for my "Shakespearean Equations," I proposed to myself not only to take liberties with the legends, but with the forms themselves, their composition, and by the addition of colour, to make them as arbitrary as the most creative work could be. I was as free to do this as any painter of fruit or faces is free to choose his subject. I do hope that my choice of the titles is as free and automatic as is yours [...]. (Grossman and Sebline 2015, 221) ${ }^{58}$

56 It seems that Man Ray took the photographs with the intention of producing paintings. He writes in his autobiography that "among the photographs I brought back to Hollywood was a batch of prints I had made in the Thirties as a basis for a series of paintings" (Man Ray 1988, 291). But then again, it may well be that Man Ray stressed the importance of the paintings over the photographs after the fact in his autobiography, wishing to be recognised first and foremost as a painter. These twists and turns have led to a debate among art historians about whether or not the photographs should be understood as artistic works in their own right or merely as preparatory studies (Werner 2002, 85-92; Hoving 2001, 193; Fortuné 1999, 2).

57 Elements of the album may be viewed on the website of the Centre Pompidou, Paris, although the titles attributed to each page appear to be wrong: www.centrepompidou.fr/id/cEBoxA/rny9Agz/en. The date 1935-1948 appears on the back of the cover. The album contains 31 contact prints showing the mathematical models, together with indications for cropping, but also annotations such as the mathematical descriptions of the objects, or the letters "T" or "C" and, crucially, the (French) titles of the Shakespearean paintings in which each model appears. It is unclear who made the annotations. Some are probably by Man Ray himself, for instance those indicating cropping. The mathematical annotations are often attributed to Michel Collinet (1904-1977), a professor of mathematics who rubbed shoulders with the Surrealists. The album now belongs to the collections of the Centre Pompidou in Paris and was exhibited for a show held from 29 April to 29 June 1998, entitled Man Ray: la photographie à lenvers (De l'Ecotais and Sayag 1998, 231). Gabriele Werner attributes at least the mathematical inscriptions to Collinet as well, citing Man Ray's secretary Lucien Treillard as a source, and discusses the significance of the album (Werner 2002, 85-92). Kirsten Hoving nonetheless seems to assume that all annotations are in Man Ray's own hand (Hoving 2001, 193). If the annotations are indeed from Man Ray and date back to the 1930s (arguably a lot of "ifs"), it would prove that Man Ray had a Shakespeare project in mind early on.

58 This undated letter from Man Ray to Breton is reproduced by Man Ray in a text entitled "A note on the Shakespearean Equations" (Grossman and Sebline 2015, 220-221), which itself is part of "To be continued unnoticed" (Schwarz 1971, 50-55), an album made by Man Ray for the 1948 Copley exhibition. 
He claims, for instance, that he called the last painting of the series All's Well That Ends Well quite simply because it was the last (Man Ray 1988, 292; Schwarz 1977, 78). Much Ado About Nothing appears as a visual pun on the title since the painting works by contrasting emptiness and fullness, but there is no apparent connection with the content of the play ${ }^{59}$ Moreover, one cannot exclude the possibility of bilingual puns. ${ }^{60}$ The specific choice of Shakespeare (rather than, say, Charles Dickens) is not accounted for. Based on this letter, Man Ray's only motivation was that Shakespeare left him space for the sort of arbitrary randomness that is typical of Surrealist creativity and freedom. Even so, the assertion that the choice of titles is arbitrary can be called into question. For example, Man Ray states that, in his Merry Wives of Windsor, "the group that represented an elliptical function reminded me of the group of merry wives of Windsor getting together to gossip and laugh" (Schwarz 1977, 79). But that means the title relates to the content of the play, which indeed features four female protagonists, and suggests Man Ray must have been familiar with the text. ${ }^{61}$

In his autobiography, Man Ray does not mention reading Shakespeare or seeing the plays performed. Nevertheless, he must have come into contact with the plays. ${ }^{62} \mathrm{He}$ also read widely and it is likely that his familiarity with Shakespeare may have been greater than the supposed arbitrariness of

59 Man Ray's painting All's Well That Ends Well can be seen here, alongside the mathematical model and Man Ray's photograph: http://blog.phillipscollection.org/2015/05/07/man-rays-shakespearean-equations-alls-ends/. Much Ado about Nothing was sold at auction in 2014 and can be seen here: www.lefigaro.fr/culture/encheres/2014/11/17/0301620141117ARTFIG00206-man-ray-triomphe-aux-encheres-a-paris.php.

60 If puns on the titles of plays are relevant, then the question of language arises: should the titles traditionally attributed to the plays in France be taken into account? After all, Man Ray produced most of the paintings while in Hollywood, but took the photographs while in Paris. An odd one out is Equation (1947; Grossman and Sebline $2015,47)$, which is the only painting not to bear a Shakespearean title although Man Ray incorporated it into the series. It is based on a 1939 ink drawing called Peine perdue (roughly: "waste of time"); the French translation of Love's Labour's Lost is Peines d'amour perdues. The painting Love's Labour's Lost (which bears no obvious resemblance to Equation; Grossman and Sebline 2015, 75) in turn features the mysterious inscription "la chaleur" ("the heat") in the bottom left corner. In short, bilingual puns are entirely possible...

${ }^{61}$ The painting The Merry Wives of Windsor, alongside the mathematical model, can be seen here: http://blog. phillipscollection.org/2015/04/13/man-rays-shakespearean-equations-merry-wives-windsor/.

62 There is early evidence of interest in Shakespeare with the 1943 painting Romeo or Juliet (which is not part of the series; Grossman and Sebline 2015, 44). Man Ray also photographed the dancer Serge Lifar in his role as Romeo in 1926 (Grossman and Sebline 2015, 160). 
the titles suggests. Yet another theory suggests a connection with art collector Walter Arensberg, who had taken a stance in the Shakespeare authorship question. ${ }^{63}$

A completely different explanation has to do with Man Ray's relocation to Hollywood. While he lived there, many film adaptations of Shakespeare were being produced. In 1947 A Double Life, which is loosely based on Othello, earned its male lead, Ronald Colman, an Academy Award. 1948 saw the release of Laurence Olivier's Hamlet and Orson Welles's Macbeth. The renewed interest in Shakespeare in the film industry may have given Man Ray the impetus for his choice of title. Finally, Andrew Strauss offers what is perhaps the most prosaic explanation:

While [Breton's] poetic titles echoed the playful Surrealist spirit of the mid-thirties, Man Ray felt that refreshing new titles in English could add to their potential popularity and commercial appeal in his new environment. The mathematical models would then become specific personalities featured in Shakespeare plays that would be familiar to his audience and invite curiosity. There were over thirty-six plays to choose from and many of their titles were household names. (Grossman and Sebline 2015, 49)

\section{Human Equations?}

At any rate, what the viewer is left with is a series of paintings that have nothing recognisably Shakespearean about them except their titles. But if these works are to be understood as adaptations, i.e. as the products of a creative process that involves examination of a first work, then one should explore what meanings Man Ray attributed to Shakespeare's plays. A first clue probably lies in the provisional title the artist had given to the series as he was painting it: human equations (Grossman and Sebline $2015,16)$. As I hope to show below with an analysis of Man Ray's King Lear, I would argue that Man Ray saw Shakespeare as a quintessentially human, if not humanist, author. Shakespeare's place high up on the pedestal of Western culture is often justified by Shakespeare's "humanism," which is not

63 Man Ray may have wished to poke fun at Walter Arensberg, an idea which goes back to James Byrnes, a curator at the Los Angeles County Museum at the time (Tashjian 1996, 100). Arensberg's New York salon had attracted many Dadaists, including Man Ray, who attended at least from 1916 onwards until his departure for Paris in 1921. Arensberg had acquired a 1917 collage by Man Ray and discarded it in the 1940s by mistake, leading to tensions between the two men. He had also taken a stance in the Shakespeare authorship question, attributing the plays to Francis Bacon on the basis of secret messages supposedly hidden in the texts by means of cryptography (Naumann 1980, 27). Man Ray would then have wished to take the opposite view as "a snide comment on Walter Arensberg's preoccupation with Francis Bacon" (Foresta 1988, 303). 
merely to be understood in reference to the intellectual movement of the Renaissance. More broadly, Shakespeare is often called a "humanist" author because he supposedly represents universal human nature, the depths of human psychology, the complexity of human relationships.

This view emerged together with the phenomenon now dubbed "Bardolatry" in the eighteenth century. Britain and Germany were seeking to establish a national identity and literature by opposition to the then dominant French model, perceived as too rigidly formalistic. Shakespeare, in contrast, was seen as being true to nature and became the ideal tool for this political and cultural project (Bate 2003). ${ }^{64}$ But other factors were also at play in making Shakespeare the Bard of human nature:

The variety and psychological complexity of [Shakespeare's] characters invited endless analysis and speculation in accordance with the eighteenth- and nineteenth-century fascination with individuality and the human mind; the rise of Bardolatry coincided with the rise of the novel and the birth of the science of psychology. (Bate 2003, 16)

At least among some scholars, this assessment endures into the present day. Harold Bloom, for instance, believed the eighteenth century had a point: "We owe Shakespeare everything, [Samuel] Johnson says, and means that Shakespeare has taught us to understand human nature" (Bloom 1998, 2); "Shakespeare, according to Johnson, justly imitates essential human nature, which is universal and not a social phenomenon" (Bloom 1998, 3, Bloom's emphasis). These comments appear in a chapter entitled "Shakespeare's Universalism," itself published in a book called Shakespeare: the Invention of the Human. Shakespeare's humanism and his universalism, by this account, are the same thing. The argument is the following: since he represents human nature, whose essence is purportedly the same beyond differences of time and space, culture, social class, gender, race, etc., Shakespeare can be universally understood and appreciated. ${ }^{65}$ This assessment of Shakespeare, however, has been rejected

64 Shakespeare painting, which also emerged in the eighteenth century, constituted one more facet of this endeavour, the Bard being regarded "as representative of the instinctive, untutored power that was the essence of the national imagination” (Sillars 2006, 1). This explains, among other things, the treatment of landscape in eighteenth-century Shakespeare painting: "The one strand that runs through almost all later landscapes is a stress on apparently uncultivated natural forms as a reflection of the instinctive, untamed freedom of the English spirit: it is the most complete visualisation of Shakespeare as the instinctive genius whose identity with the English countryside had been established in the 1740s [...].” (Sillars 2006, 16).

65 This view can extend to Shakespeare painting as well, as for instance with J. M. W. Turner: "John Ruskin was fond of applying the epithet 'Shakespearean' to Turner. He saw the great landscape painter as a supreme genius, comprehending in his titanic vision all of nature and all humanity - all the human condition" (Wilton 1994, 15). 
by most scholars and academics in recent decades, arguing that both author and reader / spectator are caught up in specific circumstances which inform their production and perception of the texts. According to Marjorie Garber, there is even a certain danger in what she calls "the rhetoric of high humanism" (Garber 1990, 244): Shakespeare "has come to stand for a kind of 'humanness' that, purporting to be inclusive of race, class, and gender, is in fact the neutralising (or neutering) of those potent discourses" (Garber 1990, 250).

This short summary of course risks oversimplifying both positions. We also find ourselves on somewhat unsafe ground. The humanist view of Shakespeare is today clearly and unambiguously rejected by the vast majority of scholars as a superseded and outdated approach of the past. On this subject, Bloom represented very much the minority view. Writing as I do in the $21^{\text {st }}$ century, I cannot and do not ignore the contributions of newer critical approaches such as new historicism, cultural materialism, feminist studies, postcolonial theory, etc., to name but a few. I would argue that Garber is right in claiming that Shakespeare's alleged "humanness" neutralises necessary perspectives and discourses.

Nevertheless, even though I do not myself share this view, it should be noted that "Shakespeare as universal, essential and timeless humanist" is an opinion that is still very much alive outside of academic circles, in one form or another. It is often used to explain Shakespeare's appeal across cultural boundaries, for instance in newspapers. ${ }^{66}$ This division between interpretive communities has itself become an object of academic study. Peter Erickson, for instance, notes that "it is as though our perceptions of Shakespeare have suddenly split into two opposed images - one critical, the other

66 Only three examples shall be given here, deliberately taken from different cultural backgrounds. Commemorating the $400^{\text {th }}$ anniversary of the Bard's death, Swiss newspaper Le Temps writes: "But of course, Shakespeare does not only owe his power to his language. That language is used to express a thought which [...] remains attuned to a certain approach to reality whose most striking characteristic is, perhaps, its universality." The article goes on to quote William Hazlitt at length, a critic of the Romantic era whose vision of Shakespeare is now seen as outdated in academic circles. About Hamlet the article says: "The prince's melancholy, with all its touching lucidity, does not prevent him from understanding both the high and low of man, both his closeness with the gods and his proximity to the dust" (John E. Jackson. 2016. "Shakespeare, les raisons du succès." Le Temps, 22 April 2016). French newspaper Le Monde, commenting on a 2013 theatre season replete with Molière and Shakespeare, compares the two men's work and concludes: "If so many directors are putting on their plays, it is because, beyond differences of time and form, they see just how universal both authors are, forever brothers in genius" (Armelle Héliot. 2013. "Shakespeare et Molière: deux visions du monde." Le Monde, 13 September 2013). German news outlet Deutsche Welle lauds a production of Love's Labour's Lost in Afghanistan by Corinne Jaber, a director with German and Syrian roots, quoting her as saying that Shakespeare is universal and timeless, fitting into any culture (Birgit Görtz. 2012. “Was hat Shakespeare mit Afghanistan zu tun?” Deutsche Welle, 14 June 2012). 
adulatory" (Erickson 1992, 56). The latter is put forth by a group who "are not professional Shakespeare critics, but rely on Shakespeare as a mainstay to bolster a universalised conception of literary heritage." The critical stance is represented by a group with which Erickson aligns himself and is "composed of Shakespeareans who have turned to historical modes of criticism in order to oppose the image of Shakespeare's art as the transcendent articulation of universal human concerns." The result, according to Erickson, is a paradox: "commentators primarily from outside professional Shakespeare studies strive assiduously to defend Shakespeare's universalism, while major scholars within the field seek with equal ardour to undermine it" (Erickson 1992, 57). ${ }^{67}$

As we have shown earlier, Man Ray's knowledge of Shakespeare's plays was probably better than he himself acknowledged when he claimed to have chosen his titles randomly. Nonetheless, he was clearly not a Shakespeare scholar in the academic sense of the word. Moreover, he was working in the 1940s and 1950s, a time when the humanist view of Shakespeare was still very much alive, even in some academic circles. If "adapters are first interpreters and then creators" (Hutcheon 2006, 18), then the commonly accepted interpretation, with reference to which Man Ray positions his own reading, was the humanist interpretation. So how does Man Ray define his position with respect to this view of Shakespeare? In his paintings, he replaces the human form with mathematical models (albeit anthropomorphised ones), inorganic objects generated automatically as the result of equations. This could be read as a radical gesture: Shakespeare, the unique genius who plumbed the depths of human psychology, replaced with mere objects. ${ }^{68}$ This interpretation would be in keeping with attitudes to mathematics in artistic circles of the early twentieth century and with Man Ray's treatment of the human form elsewhere in his work.

Mathematical knowledge was revolutionised in the 1820s with the exploration of n-dimensional and non-Euclidean geometry. These ideas started to be popularised in the 1860 s and sparked a debate about their philosophical implications in France from the 1880s onwards, a controversy which extended into the twentieth century with the writings of Henri Poincaré and Gaston Bachelard. These writings circulated widely in artistic circles. The Cubist, Dadaist and Surrealist movements found inspiration in

67 In a similar vein, the calls for papers for the 2020 MLA Annual Convention include a panel organised by Andras Kisery from City University of New York, entitled "Shakespeare: Amateur Hour" to study the "relationship among professionals, enthusiasts, fan cultures [...]" and "control of or access to cultural capital" (https://mla.confex.com/ mla/2020/webprogrampreliminary/Paper8187.html).

68 Man Ray's gesture could also be read as subversive with regard to the tradition of Shakespeare paintings, which often focused on humanism and psychology (see notes 15 and 16). 
the idea of the fourth dimension, and non-Euclidean geometry offered new possibilities for abandoning traditional linear perspective (Dalrymple Henderson 1983; Werner 2002; Fortuné 1999). ${ }^{69}$ Until then, both classical and Renaissance mathematicians had not only believed that space constituted an absolute system of reference, timeless and universal. They had also made this belief the foundation of their definition of beauty and ideal proportion in art. But the new mathematical ideas had a profound influence on artistic circles. Old positivist and rationalist certainties were blown away, which many artists saw as a form of liberation from e.g. the constraints of linear perspective. ${ }^{70}$

This relativism extends to the treatment of the human form in Man Ray's work. In his pictures, he often distorts human bodies to create interesting shapes, and he photographs them as though they were sculptures and vice versa, blurring the limit between organic and dead matter. The human body is thus no longer the ideal of perfection and proportion which art must aspire to imitate; it is at the service of art

69 The influence of the new geometry can be traced in the art of Max Ernst, who used the IHP's mathematical models in some of his own works. It is also found, for instance, in Marcel Duchamp's The Bride Stripped Bare by Her Bachelors, Even a.k.a. The Large Glass (1915-1923, www.philamuseum.org/collections/permanent/54149.html).

70 The Renaissance and the Enlightenment still believed in absolute truths inherited from Plato and Euclid: "Kepler, Galileo and Newton each saw himself as discovering geometric patterns in nature that had been put there by a Christian God" (Gamwell 2016, 64). But the discovery that space was not an objective given, that for two millennia mankind had worked on a mere fraction of the field of geometry, that what had been taken for timeless truths were in fact mere conventions, shook these beliefs to their core: "Non-Euclidean geometry [...] substantially shook the foundations of mathematics and science, branches of learning that for two thousand years had depended on the truth of Euclid's axioms. As a result, optimistic belief in man's ability to acquire absolute truth gradually gave way during the later nineteenth century to a recognition of the relativity of knowledge. [...] non-Euclidean geometry contributed substantially to the demise of traditional positivism. For certain artists in the early twentieth century, non-Euclidean geometry was to be synonymous with the rejection of tradition and even with revolution" (Dalrymple Henderson 1983, 17). Painting had often relied on mathematics to produce harmony and beauty, for instance with the discovery of linear perspective in fifteenth-century Italy. But this defining feature of Renaissance art was once again called into question by the introduction of non-Euclidean geometry, with its obvious influence on Cubism: "The existence of curved space would necessarily invalidate the linear perspective system, whose dominance since the Renaissance was being challenged by the end of the nineteenth century. Likewise, traditional means of rendering objects could hardly be adequate if no absolute, unchanging form for an object could be posited" (Dalrymple Henderson 1983, 6). Gavin Parkinson retraces in detail how Breton's understanding of science developed (esp. thanks to his friendship with Paul Valéry and Gaston Bachelard) and influenced his 1936 essay "Crise de l'objet", alongside which Man Ray's photographs were first published (Parkinson 2008). 
and can be cut up or deformed to suit the artist's needs. ${ }^{71}$ Shakespeare might be seen as an embodiment of these Renaissance and humanist notions, a writer who puts the drama of a universal and unchanging human nature, the question of man's relationship with the world, an ideal of universal order against which the state of the world is measured, centre stage. Taking the human form that had been celebrated for centuries as the yardstick of ideal proportion and replacing it precisely with those mathematical models that stood for new geometries and the relativism of human knowledge - this could be read as knocking Shakespeare the icon, and all that it stands for, off its pedestal. The paintings thus illustrate an author who often passes for the embodiment of humanism while doing away with the humans.

71 This treatment of the human form is evident in many of Man Ray's works, for instance the famous Violon d'Ingres (1924, www.centrepompidou.fr/id/cz9nA9/rxARkqz/en), or the no less famous Noire et Blanche (1926, www. moma.org/collection/works/46738). His mixture of human flesh and inanimate matter can be seen for instance in Nu et Vénus (1937, www.centrepompidou.fr/id/cpXLyG/rpqBnx/en) or Coat-Stand (1920, www.centrepompidou. $\mathrm{fr} / \mathrm{id} / \mathrm{czzAepB} / \mathrm{rXKKqz/en})$. For classical and Renaissance thinkers, the human form and its treatment in sculpture were connected to mathematics through an ideal of proportion and order: "In classical times the Pythagoreans and Plato described the universe as having an elegant geometric order. [...] they established the classical ideal of beauty as the harmonic relation of parts within a whole. Ancient and Renaissance systems of proportion were based, in part, on measurements of the human body, whose harmonious parts where seen as an immutable embodiment of beauty in the image of its divine Creator" (Gamwell 2016, 73). But by mixing human and inanimate forms, Man Ray does not necessarily reaffirm this Renaissance ideal of harmonious proportion. The effect is rather to subvert both traditional ideals of the beautiful in sculpture and the primacy of the human form: "No longer ideally separate and aloof, the ancient forms merge with our own [...]. Humanising involves lowering and leveling operations that loosen the boundaries between aesthetic idealism and human frailty" (Hoving 2005, 130). Although this approach can be seen as debasing and - when the female form is cut into pieces - misogynistic, it is synonymous with artistic freedom, especially in the context of Surrealism: "the tradition [classical sculpture] represents [is] contained, limited, and fetishised by the modern artist who can choose on what terms to 'restore' the antique. [...] When Venus can be beheaded, when a neoclassical nude can become a violin, when real bodies can turn into marble or melt into liquidity, the rules that govern the way things are give way to a new universe of possibilities. For Surrealists, it was crucial that beauty not be a fixed concept, as it had been in the past, but that its centre of gravity be constantly shifting, that beauty be open to metamorphosis" (Hoving 2005, 132-133). The exemplary authority of the "model" is also called into question. Just as mathematical objects were used around 1900 to teach students about geometry, models of classical sculptures were used to teach aspiring artists. According to Adina Kamien-Kazhdan, "much like the mathematical casts featured in Man Ray's work, the plaster casts he utilised as figures reflect his subversion of academic forms for the purpose of creating alternative representations of the human body" (Grossman and Sebline 2015, 161). As a result, "Man Ray concomitantly adopted and undermined fundamental elements of Winckelmann's Neoclassicism as related to this conception of human perfection" (Grossman and Sebline 2015, 162). My argument is that Man Ray's treatment of the human form and classical sculpture is similar to his treatment of Shakespeare as a humanist author. 


\section{King Lear: a wheel of fire}

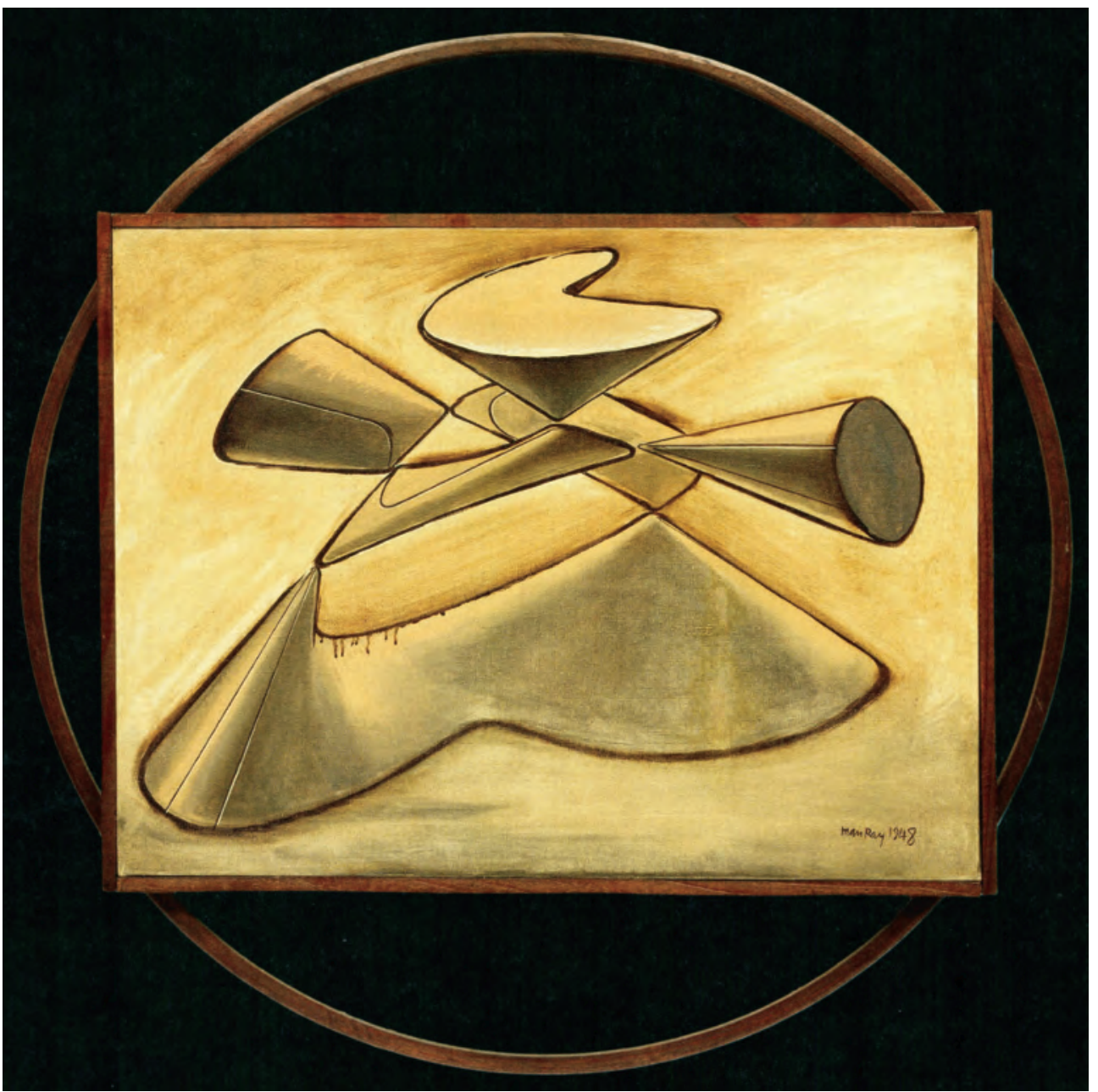

Fig. 1. Man Ray. King Lear. 1948. Oil on canvas, mounted in the artist's frame. 46x61 cm. Smithsonian Institution, Washington D. C. 
A painting which represents this possible interpretation of Man Ray's artistic gesture is King Lear. He claimed that "the colour had dripped somewhat, it looked like tears, I called the painting King Lear" (Schwarz 1977, 78). The painting could thus depict the episodes on the heath, an impression further reinforced by the fact that the mathematical model is reminiscent of a human body with arms outstretched, Lear's traditional pose in those scenes. But what should be made of the square and circle which encase the image? These are in fact three dimensional wooden frames which make the painting jut out from the wall. ${ }^{72}$ Together with the use of a yellowish colour, they point to the famous Vitruvian Man by Leonardo da Vinci, whom Man Ray calls "my favourite old master" (Man Ray 1988, 292).

In this iconic picture, man is shown as a part of a divine order based on ideal proportions. But as a rational subject, he is also able to discover and reproduce these proportions. One of the most famous depictions of the ideal harmony of the human body in relation

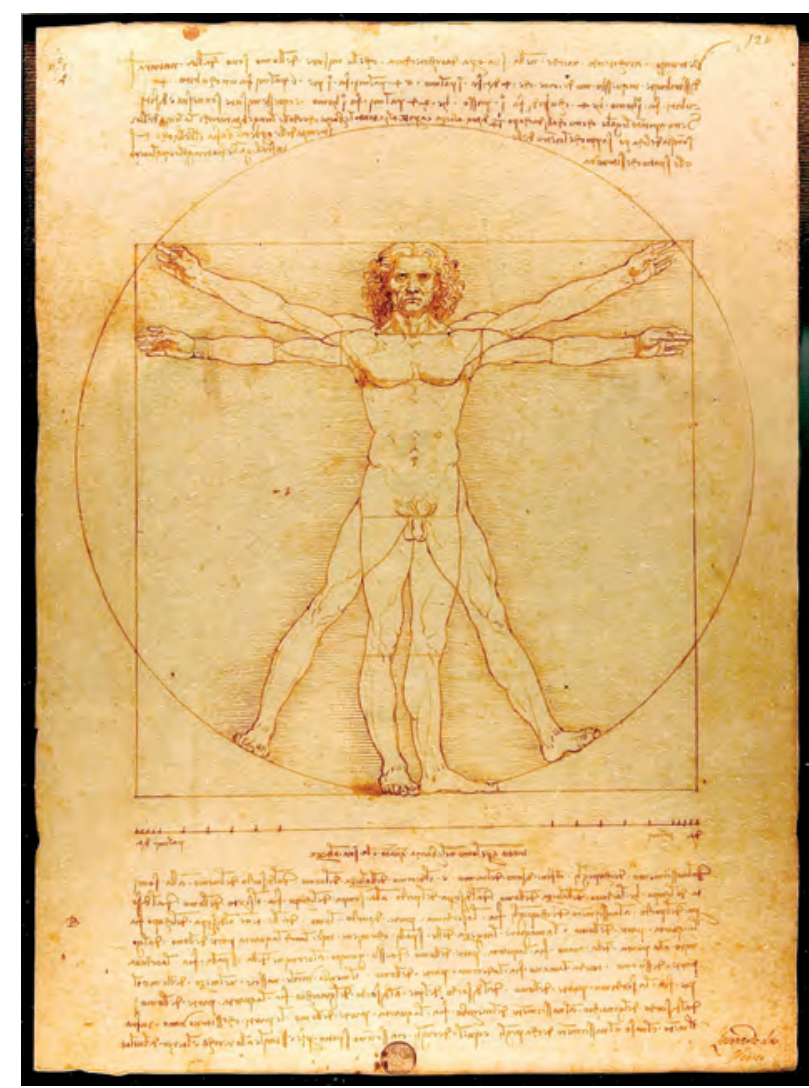

Fig. 2. Leonardo da Vinci. Vitruvian Man. Ca. 1490. Pen and ink on paper. $34 \times 25 \mathrm{~cm}$. Gallerie dell'Accademia, Venice.

72 The effect is visible in this video presenting the 2015 exhibition: www.phillipscollection.org/multimedia?id=/ multimedia/2015-02-07-exhibition-man-ray. There is a clear reference to the mathematical problem of the squaring of the circle, which had been proposed by ancient geometers and proven to be impossible to solve in 1882 . Man Ray, however, once dreamed that he had found the solution and thus produced his painting La Quadrature (1938; see Grossman and Sebline 2015, 189; Man Ray 2016, 433). 
to mathematics is used here in a double reference to the Renaissance: the visual art of da Vinci, the literary art of Shakespeare. On the other hand, the circle calls to mind Lear's description of his woes: "I am bound / Upon a wheel of fire that mine own tears / Do scald like molten lead" (4.7.46-48). The play shows a world without natural or political order. Lear, reduced to being a "poor, bare, forked animal" (3.4.106-107) calls on thunder to destroy everything and "strike flat the thick rotundity o'the world" (3.2.7). The figure of the circle, which is recurrent in the play, underlines the gradual reduction of the king, and by implication of all humanity, to zero (Laroque 2009).

By placing his Lear in a circle, does Man Ray showcase the ideal proportions of man, or does he bind his king on the wheel? He replaces the iconic Vitruvian Man with an inorganic mathematical model whose resemblance to a human body is purely fortuitous. If this is meant to be a representation of ideal mathematical proportion, then it is the ideal proportion of a mathematical object, not of a human being. As the human is removed from the celebration of human proportion, mathematics becomes selfreferential. We are, quite literally, running in a circle. As it eliminates the human from humanism, Man Ray's King Lear thus appears to undercut Renaissance notions linking ideals of man and mathematics. ${ }^{73}$ That the mathematical model appears to bleed or cry anthropomorphises the object to some extent. It calls to mind Lear's tears and suffering, his gradual reduction to "an O without a figure" (1.4.183-184). One could also see in the dripping paint a reference to blinded Gloucester's "bleeding rings / Their precious stones new lost" (5.3.188-189). In both cases, what we are left with is not only a human being reduced to nothing, but the destruction of the very idea of humanity: an empty circle.

Of course, the play itself has been read in widely differing ways by critics and scholars. In some readings, Lear is reduced to his essential humanity, thereby learning to reevaluate his true

73 The subversive power of both Leonardo da Vinci and mathematics is found elsewhere in Surrealism. Duchamp added a moustache and goatee to the iconic Mona Lisa and called his picture L.H.O.O.Q. (1919, www.centrepompidou. fr/id/c5pXdk6/rqy6qz6/fr). When read aloud in French, this title sounds like "elle a chaud au cul," i.e. "she feels hot in the arse" or "she is horny." This would in turn inspire Salvador Dalís Self-Portrait as Mona Lisa (1954). One of the Surrealists' favourite poets, Isidore Ducasse, a.k.a. the Comte de Lautréamont, also produced a defence of mathematics as a bulwark against human folly - a defence which Man Ray quotes in his "Note on Shakespearean Equations." In The Songs of Maldoror (Les Chants de Maldoror, 1869), Lautréamont celebrates mathematics because of its "excessive coldness, consummate prudence and implacable logic," the "constancy of its iron laws," its "sublime conceptions, free from passion," because of its power to reveal "this supreme truth whose trace is visible in the order of the universe." The poet sees a contrast with "the small-mindedness of humankind and their incomparable folly," their "false pride and lies," as he discovers "in humankind, as I swam towards the deepest waters, facing the reef of hatred, their black and hideous meanness, rotting away amid deleterious miasmas, gazing admiringly at its own navel" (Lautréamont 2009, 101-105). 
needs and experience forgiveness in a new-found unity with his daughter Cordelia. Feminist readings, on the other hand, emphasise Lear's own responsibility in the tragedy. In yet another tradition (Kott 1964), the play is a Beckettian demonstration of the futility of human endeavour, in which Lear dies without acquiring any knowledge or humanity. Against this critical backdrop, it is tempting to see in Man Ray's vision an anticipation of this interpretation, which would appear more than a decade after the painting. For Jan Kott, the crucial episode of the play is the cliff scene, grotesquely played out on a perfectly empty stage, forcing both characters and spectators to acknowledge that there is nothing there, probably not even the gods. ${ }^{74}$ The Kottian Shakespeare is profoundly sceptical about the ability of human beings to make sense of their meaningless existence in an absurd world. Lacking human beings to endow them with meaning, perhaps even bare of humanity or humanism, both Man Ray's and Shakespeare's wooden 'Os' remain decidedly empty. Shakespeare is thus appropriated as a representative of humanism (in the senses outlined above) and of ideal Renaissance proportion based on traditional Euclidean mathematics... before being kicked out of the frame in a way that radically questions these ideals.

\section{Why mathematics?}

So far, we have focused on an interpretation of Man Ray's paintings from a literary perspective, treating them as adaptations of Shakespeare. But given the nature of these pictures, an analysis from the perspective of mathematics is equally valid. The point of view of this other interpretive community - mathematicians or, more widely, people interested in or with a working knowledge of mathematics

74 What for Jan Kott is the key grotesque scene of the play, Edgar's description of the cliff of Dover, relies heavily on linear perspective, the great discovery of Renaissance painting. Pretending to look down, he foreshortens the things he feigns to see, claiming that a man halfway down the cliff gathering samphire "seems no bigger than his head," that the fishermen at the bottom "appear like mice," and that "yon tall anchoring barque" seems "diminished to her cock, her cock a buoy." As one might expect, the nonexistent vista ends in a vanishing point "almost too small for sight" where even hearing fails, since the water "cannot be heard so high" (4.6.11-24). Perspective is denounced as a mere optical illusion. The passage is littered with words such as "appear" or "seem." The illusion works because Gloucester is blind, suggesting that the audience, falling into the trap of the conventions of the Renaissance stage, is equally unseeing. As Jonathan Goldberg brilliantly demonstrates, "the limits that Dover represents in the text are the limits of representation themselves" (Goldberg 1984, 539). Stephen Mead shows that Nicholas Hilliard and other English Renaissance painters believed perspective to be a "device of deceit" (Mead 2012, 229) and argues that Shakespeare shared this view. The logical conclusion would be that it is not necessarily Man Ray who calls into question Renaissance ideals of true proportion and correct optical representation, but Shakespeare himself who - according to all three critics mentioned here - emerges as a profoundly sceptical author. 
- is no less legitimate. But this is where tension between the perceptions of different interpretive communities appears. If Man Ray clearly announces a deliberate Shakespearean reference through his titles, he ipso facto erases the mathematical meaning of his paintings. The fact that the paintings depict mathematical models is buried under the Shakespearean captions. To the untrained eye, it is not necessarily apparent that mathematical models are represented - one could be forgiven for thinking that Man Ray found these shapes in his own imagination.

But even for trained mathematicians the reference might not be immediately obvious. First, because time is a factor. A mathematician working around 1900 would probably have recognised the models for what they are, since they were so prevalent in university teaching at the time. But what about a mathematician working in the 1930s, when the models at the IHP were gathering dust? What about today?

Moreover, mathematics is an extremely wide field with many different sub-specialisations. Some mathematicians might immediately read the paintings as depictions of models, while others might not see the connection right away. Of course, paratext also has a role to play, for instance if the pictures are displayed alongside mathematical explanations.

My previous interpretation, arguing that Man Ray uses a reference to mathematics to undermine the cultural authority of Shakespeare, and everything that is associated with the Bard, relies on an interpretive community which is aware of academic readings of King Lear. However, that interpretation can be turned on its head. From the standpoint of mathematics, the radical gesture might reside in erasing the mathematical meaning of the models. But once again, several questions arise. What was Man Ray's knowledge of mathematics in general, and of these models in particular? What did mathematics mean in his time and how does Man Ray position himself with regard to these views?

Man Ray himself claimed that "the formulas accompanying [the models] meant nothing to me" (Man Ray 1988, 291). This assertion might once again have to be taken with a pinch of salt. Man Ray referred to the object in his Merry Wives of Windsor as representing an "elliptical function" (Schwarz 1977, 79), suggesting that he might have had some knowledge of its mathematical meaning. ${ }^{75}$ But the fact remains that Man Ray most obviously invites the spectator to see his paintings through a Shakespearean prism - by means of clear titles - rather than a mathematical one. Should one therefore

75 Here we come back to the question of the annotations in the album entitled Contacts for Shakespearean Equations (see note 8 ). Some of them refer to the mathematical meaning of the models, specifying which function or equation is represented. If these notes are in Man Ray's own hand, that would demonstrate a personal interest in this aspect. 
conclude that Man Ray opposes Shakespeare - with his supposed focus on the irrational nature of human psychology - and mathematics - with its supposed iron logic and rationality? Such a conclusion is suggested by some critics, who argue that these "equations governing rationalism - myths, of sorts, that have so suffused Western consciousness as to win almost universal consent and, hence, 'legitimacy.' It was Man Ray's avowed purpose as an artist to undermine these myths" (Foresta 1988, 254). ${ }^{76}$

\section{"Things that dream and talk in their sleep" (Tristan Tzara ${ }^{77}$ )}

Yet, taking into account Surrealist aesthetics, it becomes clear that the question whether rational mathematics is used to subvert humanist Shakespeare or the other way around is in fact moot. The poet Pierre Reverdy gave the following definition of "image" (a word which, in French, can also mean "metaphor") - a definition that would be hugely influential in Surrealist circles:

It cannot derive from a comparison, only from the juxtaposition of two realities which are more or less distant. The more the relationship of the juxtaposed realities is distant and true, the stronger the image will be - the more emotive power and poetic reality it will have. (Reverdy 1918, 3)

The poems, images and objects created in this spirit by artists notoriously obsessed with psychoanalysis and the interpretation of dreams often reveal the unconscious workings of the human mind. This endeavour lies at the heart of Man Ray's approach: "the dream in A Midsummer Night's Dream is that of two mathematical objects that dream of being transformed into butterflies - a straight line connects the objects to the flying butterflies" (Schwarz 1977, 78-79; Grossman and Sebline 2015, 67). The distant realities that Man Ray juxtaposes are "the mathematician's rational universe and Shakespeare's poetical universe" (Schwarz 1977, 78). In a dialectical poetics these opposing poles do not cancel each other out, but rather breed both a new form of knowledge and what Breton called a "convulsive" beauty (Breton 1988, 753). In the "juxtaposition of two realities which are more or less distant," references to

76 Man Ray's Julius Caesar (1948, http://blog.phillipscollection.org/2015/04/06/man-rays-shakespearean-equationsjulius-caesar/) is evidence of this subversion of mathematics. On a blackboard Man Ray writes the equation " $2+2=22$ " which of course makes no sense mathematically, but does make some form of sense for the Surrealist lateral thinker.

77 Tzara, Tristan. 1971 [1934]. "When Things Dream.” In Man Ray: 60 years of liberties, edited by Arturo Schwarz, 104-108. Paris: Eric Losfeld. 
literature, to puns and language, play a crucial role. The titles of works contribute to the meanings they can bring forth just as much as the works themselves. ${ }^{78}$

The new kinds of mathematics, with its exploration of non-Euclidean geometries, was seen as a liberation from nineteenth-century rationalism, as forming a path to this truer, more intuitive knowledge of the artist: "the late nineteenth-century resurgence of idealist philosophy provided further support for painters to proclaim the existence of a higher, four-dimensional reality, which artists alone could intuit and reveal" (Dalrymple Henderson 1983, 340). In Man Ray's photographs of the mathematical objects, "the separation between discovery by scientific means and production of knowledge by artistic means was abolished by asserting a randomness and a poetics inherent to mathematics" (Werner 2002, 22). Whether or not Man Ray commanded detailed knowledge of mathematics, non-Euclidean geometry, or indeed the specific models in front of him, may therefore not be relevant. The new mathematics popularised at the turn of the century rather took a specific place in artistic thinking, and more specifically in what might be called the Surrealist épistémè, as a tool of liberation from old traditions and production of new intuitive knowledge. If it might seem surprising to talk about an "adaptation" of mathematics in Man Ray's paintings (in the same way one might talk

78 Brigitte Hermann explains how meaning emerges from the interplay of diverse sources in Man Ray's objects: “This analogical poetry is visible in most of Man Ray's objects, which can be interpreted using a variety of entry points. The material used provides raw information, the juxtaposition of diverse elements adds a second meaning (often more than one) and the title, which is often a pun or a flourish, imprisons the object's existence in a tight net where unconscious and consciousness, objective and subjective are placed side by side, fighting and electrifying each other, endowing the object with remarkable power of life and quality of existence." The emergence of meaning in Man Ray's objects provides a pattern for understanding the interplay of mathematics and literature in the Shakespearean Equations series: "Man Ray showed [...] a small Non-Euclidean Object whose mysterious seductive power resides in the fact that 'two things that have no obvious connection in and of themselves' are made to chime together. In this object by Man Ray, the logical element and the subjective element already create a bipolarity which foreshadows the entire mathematico-poetic dream of the Shakespearean Equations" (Man Ray 1983, 9). Jean-Hubert Martin insists on the literary aspect in the emergence of meaning in Man Ray's objects: "But for a lot of objects, $[\ldots]$ the impulse comes from language, or at least from a relationship with language. [...] Transposing incongruous associations of concepts into images and objects became one of the driving forces of his work. From then on, connections of meaning were established between words and objects, in both directions, until they snowballed into ever new meanings through wordplay. This ballooning of a particularly perverse kind of logic became extremely popular with Surrealists. [...] Even if some themes are directly taken from literature [...], these juxtapositions work independently. They are never a mere illustration of a text. If they have a special relationship with the world of words, it is only to disrupt our usual thought patterns and create chains of images and ideas that offer a way of approaching reality which is more stimulating and rich than that proposed by rationalism" (Man Ray 1983, 6; see also Man Ray 2016, 432-433). 
about an adaptation of Shakespeare in the pictures), I believe this to be justified in this particular case. Man Ray might not reference a specific equation, but he does tap into a field of mathematics which had a precise meaning in the Surrealist context.

The ability of mathematics to produce poetic knowledge is connected to a wider debate about abstract art, which some Surrealists believed was unable to represent human emotion and lacked imagination. ${ }^{79}$ Man Ray's paintings are abstract in the sense of being difficult to decipher and understand at first sight. They are not, however, abstract in the more specific sense that art critics and historians associate with this word, since the paintings are figurative representations of real objects. Man Ray was fond of calling these kinds of paintings "non-abstractions" and viewed the mathematical objects as a solution to the dilemma. In the catalogue for a 1944 exhibition organised by a group of abstract painters, Man Ray wrote: "abstract art is [...] an adaptation of contemporary materials to serve the human equation. The abstract artist is intent on creating a work, isolated from its casual, immediate surroundings, but confirming the most universal human experience" (Foresta 1988, 303). The Surrealist definition of knowledge and beauty is thus based, not on a Renaissance belief in timeless ideal mathematical proportion and the rationality of man, but on the incongruous juxtaposition of opposite elements, creating a poetic knowledge, a convulsive beauty, allowing the artist to reveal how the human mind works at its most intuitive, unconscious level.

In Man Ray's paintings, as we have seen, the polar opposites of humanist Shakespeare and rational mathematics are indeed used as such. To some extent, one is invoked to subvert the other. However, that should not lead to the conclusion that one can claim supremacy over the other. In my interpretation of King Lear I have argued that, by removing the human from what has often been read as a humanist play, Man Ray questions the humanism that Shakespeare is often associated with. But from the point of view of a different interpretive community, it is the mathematics that disappears behind an exploration of Shakespeare's humanism. My previous interpretation therefore needs qualifying. The painting can be read as a celebration of the evocative power of art, mathematics and literature through a juxtaposition which threatens to annihilate them all, yet maintains them in a careful balance that shows the intuitive knowledge they can create together.

79 The inner conflict inside the Surrealist movement and Man Ray's position is summed up by Edouard Sebline (Grossman and Sebline 2015, 86-90). The 1936 special issue of Cahiers d'art in which Man Ray's photographs of the mathematical models were first published contained two essays on this subject by Christian Zervos and André Breton. 


\section{Hamlet: the counterfeit presentment of two breasts}

How fertile these poetic juxtapositions can be is perhaps best exemplified by Man Ray's Hamlet. This is how the artist explains his own picture, followed by a short comment from Arturo Schwarz:

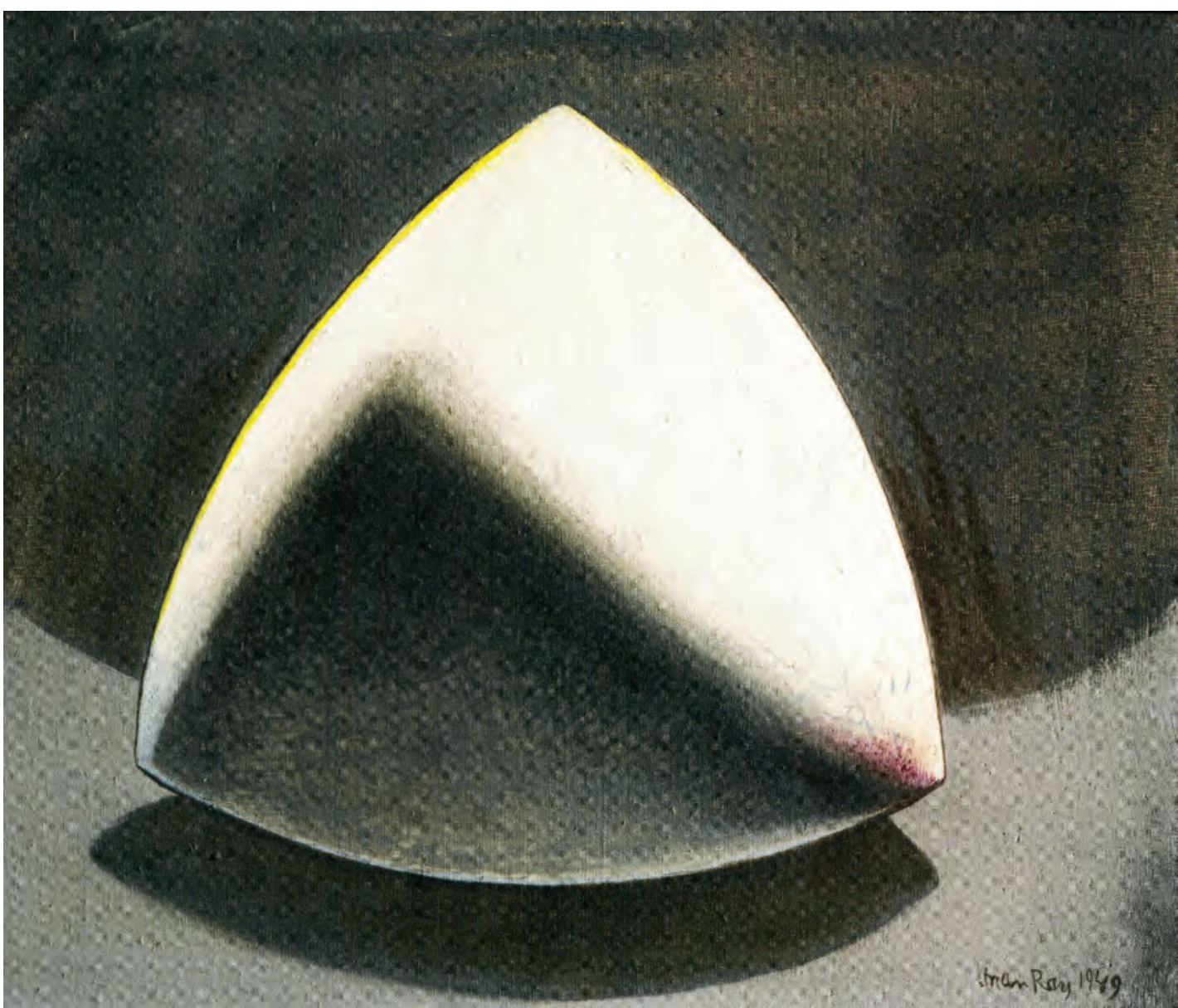

Fig. 3. Man Ray. Hamlet. 1949. Oil on canvas. 40.5x51cm. The Cleveland Museum of Art. 
The white triangular bulging shape that you see in Hamlet reminded me of a white skull, a geometric skull that also looks like Ophelia's breast. So I added a small pink dot at one of the three corners - an erotical touch, if you will! [This association of Eros and Thanatos, a favourite theme among artists of all periods, is offered here in a quite singular perspective.] (Schwarz 1977, 79)

The association of Hamlet and a skull is obvious, and the black background is reminiscent of the graveyard where the famous scene takes place. But what is usually depicted is Hamlet with a skull, not the skull on its own. The painting thus plays with the visual habits of the viewer: when we see a painting entitled Hamlet, we expect a depiction of the prince. Thus, we are perhaps not looking at Yorick's skull, but Hamlet's. The painting would then show what happens after the play has ended, Hamlet has been buried alongside the old jester and his "too too sullied flesh" has indeed melted (1.2.129). Here the memento mori can no longer teach Hamlet about the vanity of human endeavour and the pain of loss - he is the memento mori.

There may also be a reference to an extremely cerebral character, whose skull appears in the painting as "a dull head among windy spaces," as in T. S. Eliot's "Gerontion." He is represented as a character who spent the better part of the play thinking about life and death, wondering if he should be or not be. The great question of the text is here finally answered, and in the negative, perhaps suggesting that its endless back and forth on the question of suicide may have been vain. ${ }^{80}$ The end of the play and the end of its protagonist are both rendered predictable by the tragic mechanism which makes these moments coincide; the skull symbolises both. And yet, after the curtain has fallen, something remains. This is an object whose insistent materiality seems to deny Hamlet his oft-repeated wish to dissolve into absolute nothingness. It thereby answers Hamlet's other question in the play, that about the possible existence of "the undiscover'd country, from whose bourn / No traveller returns" (3.1.7980). The materiality of the skull suggests that the dream which Hamlet fears he will dream after death does not exist, that what is left after consciousness ends is a heap of bones.

The other interpretation offered by Man Ray is no less fecund. According to a 1948 letter by Man Ray, the entire series originated partly in an interest in the erotic: "I've been working all year

80 Once again, different interpretive communities might arrive at different conclusions. For many casual readers and spectators of Shakespeare, the skull is not connected to the graveyard scene (5.1), it is rather connected to the famous "To be or not to be" soliloquy (3.1). In fact, the association has become a staple of references to Hamlet in popular culture. As far as Man Ray's painting is concerned, the association between a skull and the prince's musings on life and death might therefore appear even more obvious to this audience. 
since my trip to Paris and produced a whole new series of paintings based on mathematical equations from an erotic standpoint - very discreet!" (Grossman and Sebline 2015, 160). Given that the series was successively entitled Human Equations and Shakespearean Equations, this suggests that Man Ray may have seen the exploration of human nature, Shakespeare, and sexuality as overlapping. Schwarz's remark rightly underscores the association of eroticism (the pink dot with its evanescent suggestiveness) and death (the troubling whiteness of this breast, cut off from its owner). If there is eroticism here, it is that of the blazon, which in order to flatter its object must chop it to pieces. With its Eros and Thanatos motif, Man Ray's painting echoes the play itself where Gertrude, as she mourns Ophelia, associates sexuality and death: "I hop'd thou shouldst have been my Hamlet's wife: / I thought

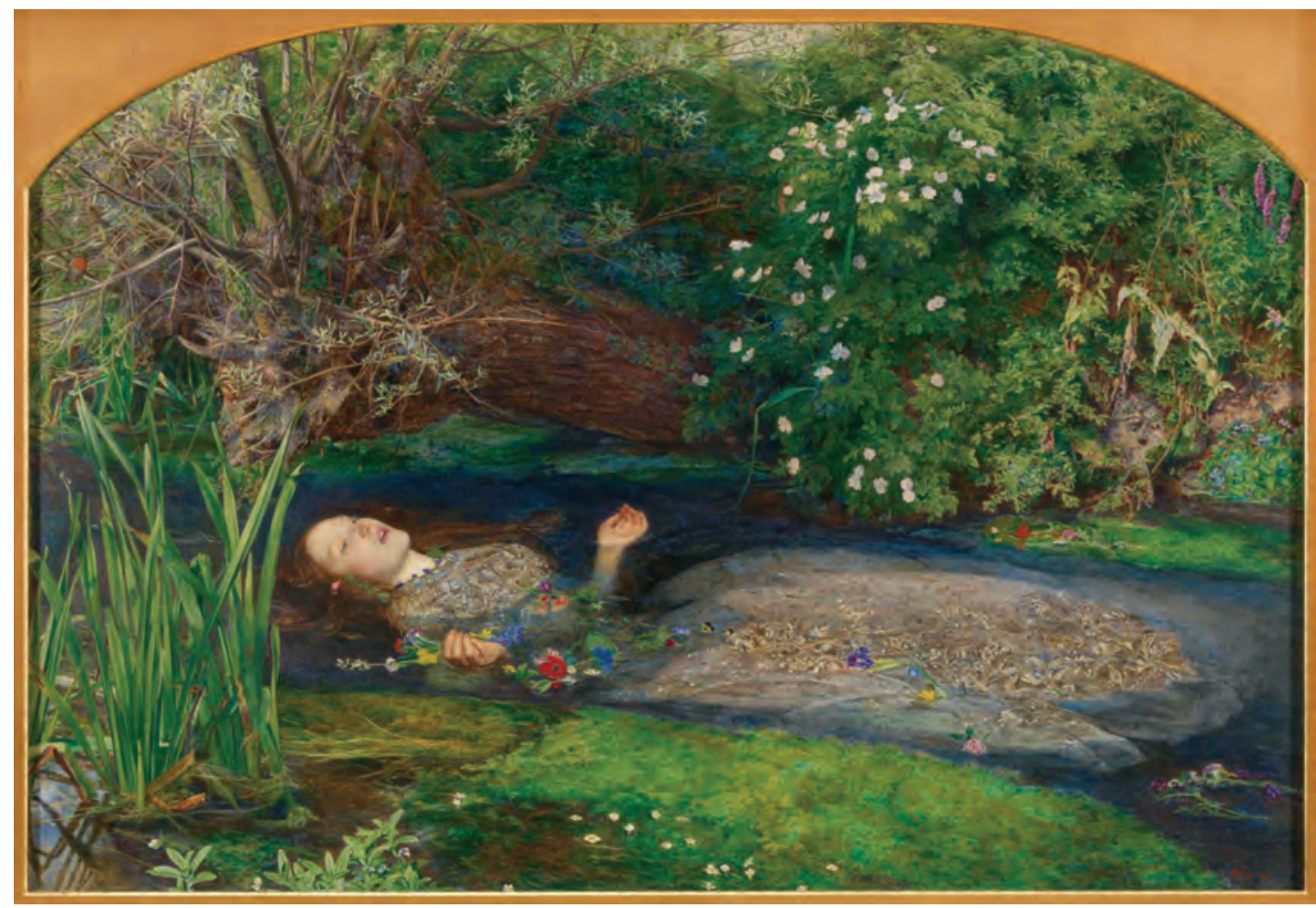

Fig. 4. Sir John Everett Millais. Ophelia. 1851-1852. Oil on canvas. $111.8 \times 76.2 \mathrm{~cm}$. Tate Britain, London. 
thy bride-bed to have deck'd, sweet maid, / And not have strew'd thy grave" (5.1.242-244). It is also reminiscent of this most famous depiction of Ophelia: the painting by Millais, which Olivier used as inspiration for his 1948 film adaptation.

In this Pre-Raphaelite icon, the young woman is dressed in white, a colour which symbolises her virginity. But it is also reminiscent of a wedding dress and thereby suggests the lawful sexual relationship with her lover that Ophelia never experienced. Her arms are outstretched as if to receive him, her lips are parted as if they awaited his kiss, her eyes are open as if she expected to see him at any moment. The young woman is sinking but has not quite sunk yet - her breast is still above the waterline - and she is shown precisely in the second when she is suspended between life and death. By painting something that looks both like a breast and an inorganic object, Man Ray similarly suspends his picture between life and death, Eros and Thanatos. Playing with "objectification of the human and eroticisation of form," as Alexa Huang puts it (Grossman and Sebline 2015, 174), Man Ray's painting appears both more explicitly erotic than Millais's and less so. Almost like a portrait by Julian Opie, which seeks to reduce a face's features to their bare minimum without making the subject unrecognisable, Millais is reduced to one element which abridges all the rest. Man Ray's work both belies and reaffirms the iconicity of both Shakespeare and Millais: it relies on their fame to be understood while contending that it is possible to do without them.

But the picture may have had a much more obvious source, as Ophelia's female attributes are explicitly mentioned in the play. Attempting to prove to Claudius and Gertrude that Hamlet's strange behaviour has to do with his daughter, Polonius reads to them a letter written by the prince which mentions "her excellent white bosom" (2.2.112). One can easily imagine Polonius's embarrassment as he realises a little too late just how intimate the letter is. Gertrude saves him by interrupting with a question ("Came this from Hamlet to her?" 2.2.113) and the spectator, regrettably, will never find out exactly what Hamlet had to say about Ophelia's bosom. Although Polonius ridicules himself by commenting on the letter's stylistic qualities (or the lack thereof), the scene is evidence of his absolute ruthlessness as a courtier, who does not hesitate to expose his daughter's private affairs in public to ingratiate himself with the new man in charge.

In a play over-brimming with Freudian slippages, this episode contains the merest hint of an Oedipal proximity between daughter and father as the latter publicly discusses the sexual attributes of the former. Her unfaltering loyalty to her father throughout the play could point in the same direction. On the other hand, Hamlet also uses her as an audience to whom he performs his outer show of madness and cruelly pretends that "I loved you not" (3.1.119). Ophelia finds herself trapped between 
two consummate courtiers who are both willing to sacrifice her in order to survive in the unforgiving world of Elsinore. This makes it impossible for her to transfer any Oedipal tendencies onto a mature sexual relationship with Hamlet. Torn apart by this tension, she dies. Man Ray's blazon-like picture of her "excellent white bosom" shows her reduced to a mere object. She is the object of the eroticising male gaze of her father, her king and her lover in a scene from which she is, tellingly, absent. She is the object of the eroticising male gaze of Man Ray himself. She is, perhaps, the object of the eroticising (male?) gaze of the viewer. She is a mathematical object which can be handled like a prop.

But the aforementioned scene does not only feature a father discussing his daughter's sexuality, it also shows a mother hearing about her son's sexuality and interrupting at the most evidently Freudian moment. The Oedipal overtones of Hamlet's and Gertrude's relationship are a well-known classic of Shakespeare scholarship; they influenced Olivier's performance in his 1948 film adaptation (Donaldson 1987). Why not see Gertrude's breast in the painting? The Ghost asks his son not to "contrive / Against thy mother aught" and to leave her "to those thorns that in her bosom lodge / To prick and sting her" (1.5.85-88). The young prince spends a sizeable portion of the play trying to figure out what exactly is going on in his mother's breast, fearing that it has been invaded by the blackness that Man Ray shows in his picture. The painting could thus be read as an allusion to this other Oedipal relationship in the play, and Hamlet's own failure to transfer his affections onto a more suitable partner. Huang concludes that "the painting symbolises the often objectified and silenced women characters in the play" (Grossman and Sebline 2015, 174). The title of the painting would then refer to, not exactly a portrait of the prince, but rather a portrait of his unconscious mind, dominated by the blackness of mourning, an Oedipal relationship with his mother, a failed erotic relationship with his lover. Is this effect achieved in spite of, or rather thanks to, the mathematical reference? For Surrealists the intuitive knowledge their works produced was often associated with sexuality and psychoanalysis, revealing how the unconscious mind works. Man Ray's Hamlet yokes together mathematics and literature to do just that.

\section{Conclusion: a portrait of the artist as a young iconoclast}

If these paintings are read as adaptations, therefore, they create a dialogue, in the context of Surrealist aesthetics, between the place attributed to Shakespeare and to mathematics in Surrealist thinking and wider twentieth-century culture. Each facet must be taken into account to produce a full understanding of the knowledge - in the Surrealist sense of the word - that is generated by their juxtaposition. According to Man Ray, artists deal with "the most universal human experience" (Foresta 1988, 303). Although this vision of Shakespeare has long been rejected by academia, I would argue that, here, Shakespeare 
is used as a prism through which the paintings explore the human psyche. Perhaps surprisingly, nonEuclidean geometry, in that it frees the artist from previous constraints of representation, serves a similar purpose.

But these interpretations, enclosed as potentialities in the paintings, are only realised when certain interpretive communities are at work. The mathematician, the Surrealist, the literary scholar or the general public probably do not see the same thing when looking at these pictures. This would be true of any painting, but perhaps even more so in this case, where such diverse areas of knowledge are associated. In the end, they raise the question of the possibility of interpretation itself. Much of the interpretive work is left to the viewers, who must bring their knowledge to bear to make sense (if not "build" sense) out of pictures that provide few clues one can take hold of. Even viewers who know that they are looking at mathematical models would still have to bring their mathematical knowledge to bear, trying to figure out for themselves which function or equation is represented, since the artist does not provide that information. Similarly, although the viewers are provided with Shakespearean titles, in the absence of any other Shakespearean reference in the paintings themselves, the association between picture and text is something the viewers have to construct by themselves. As nondescript objects are placed in an indeterminate background with mysterious titles, the difficult job of the construction of meaning is left to the viewer. As Sebline and Strauss put it, Man Ray "leaves the spectator in charge of interpretation, an invitation which might be considered a profoundly Surrealist act" (IHP 2017, 160). As we are left to project and even read interpretations into the paintings, is relativism the logical result?

In fact, if there truly is a form of iconoclasm here, it is perhaps in the way Man Ray lays bare the mechanisms by which the mind makes sense of a picture. This could be interpreted as a joke: Man Ray mocking viewers who, upon being told that they must see Shakespeare, dutifully perform their job of seeing what the artist tells them to. Just as an object is transformed into art by virtue of an artist's signature and a display in a museum, a painting acquires all the cultural authority associated with Shakespeare when that name is inscribed in the caption - no matter what it actually depicts.

This in turn lays bare the role of the artist. He may not provide us with an authorial (or authoritative) interpretation, in the sense of a definitive meaning of a specific picture. But there is an authorial gesture in the bringing about of a process of questioning. The spectators are forced into a situation where they have to construct meaning consciously, thereby questioning what elements of the interpretive community to which they belong they bring to bear on that process. There is no right or wrong answer about any particular painting, there is merely a human mind accustomed to making sense of images in a certain way. It is precisely the recalcitrant indeterminacy of the paintings that reveals that 
what we see in the pictures is what we choose to project onto them. Man Ray, at the very least, seems to be having fun: "I used to play games with people who looked at these paintings: "what do you think this painting should be titled;' often they would guess, they would see the association" (Schwarz 1977, 78).

The person on whom the projection game works best is probably the one who has the most to project: the scholar. After spending a lifetime dissecting every last comma in plays, every last figure in equations, the researcher gets sucked most deeply into the vortex trying to make sense of the paintings. It is perhaps only to this category of viewer it would even occur to raise the question of whether Shakespeare's humanism shines through in Man Ray's paintings. Educated by a university system that often views universalism with suspicion, it is the Shakespeare scholar who brings their knowledge of this academic debate to bear on their analysis of the paintings. The issue I have chosen to explore in this essay is thus the product of a specific moment in Shakespeare criticism, and it may appear irrelevant to a different set of viewers, or to Man Ray himself. What the paintings do is perhaps "hold as 'twere the mirror up to [the] nature," not of universal man, but of a specific interpretive community whose obsessions may not be shared by all.

The irony is that an interpretive community with sufficient knowledge to project so much onto the paintings is precisely what Man Ray abolishes, especially when it comes to Shakespeare. Anyone who has heard the titles of Shakespeare plays - arguably a large group - can play the game. There are few authors who would have been famous enough to enable Man Ray to make this a game for everyone. In this sense at least, the paintings reaffirm Shakespeare's universality and put it to use for their own purposes. The pictures may, rather cheekily, purport to take the Shakespeare out of Shakespeare, the mathematics out of mathematics. But to the question "Is there a Shakespeare (or an equation) in this class?" the answer must be affirmative: it is there as a projection in the viewer's mind. What is both present and absent in these paintings is Shakespeare and mathematics themselves.

Man Ray could be seen as using mathematics to subvert the cultural authority of literature and vice versa. But in the end the projection game works only as a reaffirmation of the universality of both. If the paintings stubbornly refuse to offer a definitive reading of the plays, they do offer a reading of the way interpretations are constructed in the viewer's mind, of the way different interpretive communities approach a work, of the way Shakespeare and mathematics have been appropriated and adapted in Surrealist thinking. 


\section{WORKS CITED}

Unless otherwise stated, all translations from languages other than English are by the author.

BALDWIN, Neil. 1989. Man Ray. London: Hamish Hamilton.

BATE, Jonathan. 2003. “The Shakespeare Phenomenon.” In Shakespeare in Art, edited by Jane Martineau, 9-20. London: Dulwich Picture Gallery.

BENTON, Michael and Sally BUTCHER. 1998. "Painting Shakespeare." The Journal of Aesthetic education 32 (3): 53-66.

BLOOM, Harold. 1998. Shakespeare: the Invention of the Human. London: Fourth Estate.

BRETON, André. 1936. "Crise de l'Objet (Crisis of the Object)." Cahiers d'art 11 (1-2): 21-26.

BRETON, André. 1988 [1928]. "Nadja." In CEuvres Complètes I, edited by Marguerite Bonnet, 643-775. Paris: Gallimard.

DALRYMPLE HENDERSON, Linda. 1983. The Fourth Dimension and Non-Euclidean Geometry in Modern Art. Princeton: Princeton University Press.

DE L'ECOTAIS, Emmanuelle and Alain SAYAG, eds. 1998. Man Ray, la Photographie à l'Envers (Man Ray, Photography Upside Down). Paris: Centre Pompidou, Seuil.

DONALDSON, Peter. 1987. "Olivier, Hamlet and Freud." Cinema Journal 26 (4): 22-48.

ELUARD, Paul. 1968 [1929]. "L'amour la poésie (Love Poetry)." In (Euvres Complètes I, edited by Lucien Scheler and Marcelle Dumas, 227-265. Paris: Gallimard.

ERICKSON, Peter. 1992. “The Two Renaissances and Shakespeare's Canonical Position.” Kenyon Review 14 (2): 56-70.

FISH, Stanley. 1980. Is There a Text in This Class? The Authority of Interpretive Communities. Cambridge, MA: Harvard University Press.

FORESTA, Merry et al. 1988. Perpetual Motif: the Art of Man Ray. Washington: National Museum of American Art; New York: Abbeville Press.

FORTUNE, Isabelle. 1999. "Man Ray et les Objets Mathématiques (Man Ray and the Mathematical Objects)." Etudes Photographiques 6: 100-117.

GAMWELL, Lynn. 2016. Mathematics and Art: a Cultural History. Princeton: Princeton University Press.

GARBER, Marjorie. 1990. "Shakespeare as fetish.” Shakespeare Quarterly 41 (2): 242-250.

GOLDBERG, Jonathan. 1984. "Dover Cliff and the Conditions of Representation: King Lear 4.6 in Perspective." Poetics Today 5 (3): 537-547.

GROSSMAN, Wendy and Edouard SEBLINE, eds. 2015. Man Ray. Human Equations. A Journey from Mathematics to Shakespeare. Ostfildern: Hatje Cantz.

HOVING, Kirsten. 2001. “Abstract Vision and Satisfied Passion: Man Ray's Mathematical Objects.” History of Photography 25 (2): 193-200. 
HOVING, Kirsten. 2005. "Man Ray's Disarming Venuses: Deconstructing the Classical Torso in Surrealist Photography." History of Photography 29 (2): 123-134.

HUTCHEON, Linda. 2006. A Theory of Adaptation. New York: Routledge.

IHP [Institut Henri Poincaré], ed. 2017. Objets Mathématiques (Mathematical Objects). Prefaced by Cédric Villani and Jean-Philippe Uzan. Paris: CNRS Editions.

KOTT, Jan. 1964. Shakespeare our Contemporary. Translated by Boleslaw Taborski. London: Methuen.

LAROQUE, François. 2009. “King Lear as a vicious circle." In And that's true too: new essays on King Lear, edited by François Laroque, Pierre Iselin and Sophie Alatorre, 212-225. Newcastle: Cambridge Scholar.

LAUTREAMONT, COMTE DE. 2009 [1869]. "Les Chants de Maldoror (The Songs of Maldoror)." In Euvres Complètes, edited by Jean-Luc Steinmetz, 1-255. Paris: Gallimard.

MAN RAY. 1983. Objets de mon Affection (Objects of my Affection), edited by Jean-Hubert Martin. Paris: Philippe Sers.

MAN RAY. 1988. Self-portrait. Boston: Little, Brown \& Company. [autobiography originally published in 1963]

MAN RAY. 2016. Man Ray, Writings on Art, edited by Jennifer Mundy. Los Angeles: Getty Research Institute.

MEAD, Stephen. 2012. "Shakespeare's Play with Perspective: Sonnet 24, Hamlet, Lear." Studies in Philology 109 (3): 225-257.

NAUMANN, Francis. 1980. "Walter Conrad Arensberg: Poet, Patron, and Participant in the New York Avantgarde, 1915-1920." Philadelphia Museum of Art Bulletin 76 (328): 2-32.

PARKINSON, Gavin. 2008. Surrealism, Art and Modern Science. Relativity, Quantum Mechanics, Epistemology. New Haven: Yale University Press.

REVERDY, Paul. 1918. "L'image (The Image).” Nord-Sud 2 (13): 3-7.

ROBINSON, Arthur. 2015. "Man Ray's Human Equations." Notices of the American Mathematical Society 62 (10): 1192-1198.

SCHWARZ, Arturo, ed. 1971. Man Ray: 60 Years of Liberties. Paris: Eric Losfeld.

SCHWARZ, Arturo. 1977. Man Ray: Rigour of Imagination. London: Thames and Hudson.

SHAKESPEARE, William. 2011. Complete Works, edited by Richard Proudfoot, Ann Thompson and David Scott Kastan. The Arden Shakespeare. London: Bloomsbury.

SILLARS, Stuart. 2006. Painting Shakespeare: the Artist as Critic 1720-1820. Cambridge: Cambridge University Press. TASHJIAN, Dickran. 1996. “'A clock that forgets to run down:’ Man Ray in Holywood 1940-1951.” In Man Ray: Paris, LA. Santa Monica, New York: Smart Art Press.

WERNER, Gabriele. 2002. Mathematik im Surrealismus. Man Ray, Max Ernst, Dorothea Tanning (Mathematics in Surrealism. Man Ray, Max Ernst, Dorothea Tanning). Marburg: Jonas Verlag.

WILTON, Andrew. 1994. “Turner and Shakespeare's Jessica." History Today 44 (4): 14-19. 